\title{
Descriptive study of American tegumentary leishmaniasis in the urban area of the Municipality of Governador Valadares, Minas Gerais State, Brazil
}

Estudo descritivo sobre a leishmaniase tegumentar americana na área urbana do Município de Governador Valadares, Estado de Minas Gerais, Brasil

Estudio descriptivo sobre la leishmaniasis tegumentaria americana en el área urbana del Municipio de Governador Valadares, Estado de Minas Gerais, Brasil

Thiago Mourão de Miranda

Laboratório de Imunologia, Universidade Vale do Rio Doce,

Governador Valadares, Minas Gerais, Brasil

Luiz Cosme Cotta Malaquias

Departamento de Ciências Biomédicas, Universidade Federal de Alfenas, Alfenas, Minas Gerais, Brasil

Patrícia Maria Fonseca Escalda

Laboratório de Imunologia, Universidade Vale do Rio Doce, Governador Valadares, Minas Gerais, Brasil

Katiuscia Cardoso Ramalho

Departamento de Atenção à Saúde, Secretaria Municipal de Saúde, Governador Valadares, Minas Gerais, Brasil
Wendel Coura-Vital

Laboratório de Imunopatologia, Núcleo de Pesquisas em Ciências Biológicas, Universidade Federal de Ouro Preto, Ouro Preto, Minas Gerais, Brasil

Alexandre Rotondo da Silva

Laboratório de Imunopatologia, Núcleo de Pesquisas em Ciências Biológicas, Universidade Federal de Ouro Preto, Ouro Preto, Minas Gerais, Brasil

Rodrigo Corrêa-Oliveira

Laboratório de Imunologia Celular e Molecular, Instituto René Rachou, Fundação Oswaldo Cruz, Belo Horizonte, Minas Gerais, Brasil

Alexandre Barbosa Reis

Laboratório de Imunopatologia, Núcleo de Pesquisas em Ciências

Biológicas \& Departamento de Análises Clínicas, Escola de Farmácia,

Universidade Federal de Ouro Preto, Ouro Preto, Minas Gerais, Brasil

\begin{abstract}
To understand the emergence and re-emergence pattern of American tegumentary leishmaniasis (ATL), the clinical and epidemiological profiles and the spatial distribution of the disease were evaluated between 2001 and 2006 in an endemic area located in the Rio Doce valley in the north-eastern part of the Minas Gerais State, Brazil. The number of reported cases increased from six in the first year to 111 in the last year during this period. Disease cases predominated in the urban area $(75.9 \%)$ and affected males and females equally in all age groups. The transmission of ATL occurred within dwellings and the surrounding areas, with the largest number of reported cases originating from poor areas, particularly those located on the margins of the Rio Doce lacking suitable sanitary infrastructure. Diagnosis was based on clinical criteria and the Montenegro skin test, with most patients (93.8\%) exhibiting the cutaneous form of ATL. First-line treatment involved administration of pentavalent antimonial drugs $(99.1 \%)$, and these provided a cure for $>75 \%$ of patients. The prevalence of ATL varied between 11.38 and 15.99 cases per 100,000 inhabitants, which is high in comparison with the national average. Urgent measures, including improved means of diagnosis at the local health units, education of schoolchildren and motivation of the general population, are required to decrease transmission and control the disease.
\end{abstract}

Keywords: Leishmaniasis; Cross-Sectional Studies; Disease Notification; Urban Health; American Tegumentary Leishmaniasis.

\section{INTRODUCTION}

Leishmaniasis is caused by various protozoan members of Leishmania (Kinetoplastida: Trypanosomatidae), a genus that comprises many unicellular digenetic (heteroxenous) species'. In Latin America, the parasite is

\footnotetext{
Correspondence / Correspondência / Correspondencia:

Alexandre Barbosa Reis

Laboratório de Imunopatologia, Instituto de Ciências Exatas e Biológicas,

Universidade Federal de Ouro Preto. Morro do Cruzeiro

CEP: 35400-000 Ouro Preto-Minas Gerais-Brasil

Tel.: 55 (21) 31 3559-1694 | Fax: 55 (21) 31 3559-1680

E-mail: alexreis@nupeb.ufop.br
}

transmitted through bites of female hematophagous insects belonging to the family Phlebotominae ${ }^{2}$.

The disease is estimated to cause 1.6 million new cases annually, of which an estimated 500 thousand are visceral, and 1.1 million are cutaneous or mucocutaneous ${ }^{3}$. Overall prevalence indicates that 12 million people in 88 countries suffer from leishmaniasis, whilst 350 million people live in at-risk areas ${ }^{4}$. American tegumentary leishmaniasis (ATL) is widely distributed within the American continent, from the south of the United States to the north of Argentina ${ }^{5,6}$. In Brazil, the disease represents a serious public health problem because it has been diagnosed in most of the constituent states $^{7,8}$. 
The clinical manifestations of the disease depend on a variety of factors, including the nutritional status and immune response to infection of the individual and the diversity of vectors and parasite species involved ${ }^{9}$. ATL can emerge in three different forms: (i) cutaneous leishmaniasis characterized by single or multiple lesions, often ulcerated, in the vicinity of the insect bite; (ii) mucosal leishmaniasis characterized by the destruction of nasal and oral mucosa, and consequent disfiguration of the patient, that may occur separately or concomitantly with (i); and (iii) diffuse cutaneous leishmaniasis characterized by multiple, nonulcerated, nodular lesions that may be distant from the insect bite $^{10}$. ATL is an occupational disease because exposure is typically related to occupation, and the consequent psychological distress induced by the disease reflects on the social and economical performance of the individuals ${ }^{11,6}$.

Epidemiological studies have revealed that ATL is a zoonosis that initially affects animals and eventually humans. In man, the average incubation period is two months, although it may be somewhat shorter (around two weeks) or, more rarely, longer (up to two years) ${ }^{6}$. A definitive diagnosis of ATL depends on the clinical and epidemiological assessment of the patient, together with the results of parasitological, immunological and molecular tests ${ }^{11}$. First-line therapy consists of administration of pentavalent antimonial drugs, whereas secondary therapy includes treatment with amphotericin B and pentamidine, both of which are relatively toxic and expensive $e^{12,13,14}$. Owing to the complexity of the disease, the design of appropriate prophylactic strategies must consider all components of the Leishmania cycle including insect vectors, domestic and wild reservoirs, and susceptible and infected humans ${ }^{10}$.

The clinical and epidemiological profiles of ATL are complex by virtue of the diverse environmental, social, human and biological factors involved. Historical records clearly show that the epidemiological profile of the disease in Brazil is cyclic ${ }^{15,16,17,18}$. During the 1950s the number of ATL cases diminished, but more recently, the incidence of new, confirmed cases has risen to 30 thousand per year ${ }^{19,17}$. According to the Secretaria de Vigilância em Saúde ${ }^{6}$, the Northern Region possesses the highest coefficient of disease detection (100 cases per 100,000 inhabitants) followed by the Central-Western and the Northeastern, whilst the Southeastern Region accounts for only $10 \%$ of all reported cases.

In Minas Gerais, the largest State in the Southeastern Region of Brazil, an average of 10.5 new cases of ATL per 100,000 inhabitants were reported annually during the period 1990-2006. Furthermore, the number of affected individuals increased during this period, and the disease spread to various municipalities. In the metropolitan area of Belo Horizonte, the capital of Minas Gerais State, autochthonous cases of ATL have been registered by official health institutions since $1987^{19}$, with infection cycles varying according to climatic and social factors, such as deforestation, drought and disordered land occupation. In general terms, the incidence of ATL has been shown to be positively correlated with seasons because increases in temperature or humidity favor the multiplication of phlebotomines $^{20}$. For this reason, each geographical region presents specific characteristics that determine the pattern and complexity of ATL transmission.

ATL was first diagnosed in the Rio Doce valley, which constitutes one of the most important mining areas of Minas Gerais, in the 1960s. Mayrink and co-workers ${ }^{16}$ observed that the characteristics of ATL in the Rio Doce valley were different from those of other endemic areas in Brazil because the infected individuals had little or no contact with forest environments. Although there is some evidence for the occurrence of the disease in the Municipality of Governador Valadares since the $1940 s^{21,22}$, it has not been possible to determine the number of registered cases prior to 2001 by examination of the records maintained at the municipal, state or federal level, or from other publications. It is expected that the results of this study will contribute to the understanding of the factors associated with the emergence and re-emergence of the disease.

\section{MATERIALS AND METHODS}

\section{STUDY AREA}

The 260,396 inhabitants of Governador Valadares (latitude 1851'01" S; longitude 41 56'18" W; altitude 170 $\mathrm{m})$ are distributed within 100 urban and ten rural districts. The semi-humid, tropical climate is characterized by an average temperature of $24.5^{\circ} \mathrm{C}$, with only slight deviations during the year. Maximum precipitation occurs in the summer and autumn seasons (December to May), whilst winter is typically dry. The relative humidity is, on average, $76 \%$ in the winter and $84 \%$ in the summer. Governador Valadares represents one of the most important economic centers of the Rio Doce valley and influences human activity in all surrounding areas. The local economy is based on mining, heavy industry, commercialization of precious stones, agriculture, cattle breeding and tourism.

\section{STUDY DESIGN AND DATA COLLECTION}

The descriptive study described herein was based on data supplied by the Sistema de Informação de Agravos de Notificação (SINAN) of the Brazilian Health Ministry for the period 2001-2006. Profiles of individuals affected by ATL were established; the protocols documented sociodemographic status (age, gender, schooling and area of origin), clinical epidemiology (number of cases reported per year, clinical forms, presence of lesions and history of the disease), diagnosis (clinical and laboratory tests) and therapy (initial drug administered, evolution of the disease). Average values for variables associated with the base population during the study period were determined from the arithmetic means of the respective variables in the years 2003 and 2004, calculated on the basis of the growth estimates from the Instituto Brasileiro de Geografia e Estatística (IBGE) available at the Sistema Único de Saúde databank (DATASUS) ${ }^{23}$. The average number of ATL cases recorded per year was determined by totaling the number of cases for each variable and dividing by the total number of years evaluated (i.e., six years). The annual average prevalence was expressed as the number of ATL cases recorded per 100,000 inhabitants. 


\section{EVALUATION OF THE SPATIAL DISTRIBUTION OF ATL}

A map of the urban zone of Governador Valadares was prepared, showing the limits of the individual census sectors, according to information provided by IBGE. Each recorded ATL case was located in its respective census sector, and each sector was shaded differently according to the total number of cases. The population was divided into groups according to similarity of socio-economic and sanitary variables established by cluster analysis of data extracted from the 2000 Demographic Census databank. Additionally, the census sectors were classified into three groups according to their common characteristics, and the ATL prevalence in each group was established from the IBGE population data. All statistical analyses were performed using SPSS Data Editor for Windows (version 13.0).

\section{RESULTS}

According to SINAN, 241 cases of ATL were recorded in Governador Valadares during the period 2001-2006, and, of these, $46.10 \%$ were reported for 2006 alone. The frequencies of ATL cases distributed according to clinicalepidemiology, diagnosis and therapy parameters are shown in table 1 and according to socio-demographic parameters in table 2. Most of the affected individuals lived in the urban zone (75.93\%) and were males (52.70\%). The annual average prevalence of infection was 17.49 per 100,000 males and 14.39 per 100,000 females. The majority (approximately 68\%) of the infected population had attended school for a maximum of only 11 years.

Table 1- Frequencies of ATL cases notified in Governador Valadares during the period 2001-2006 distributed according to socio-demographic status, clinical-epidemiology, method of diagnosis and first-line therapy employed

\begin{tabular}{llcc}
\hline $\begin{array}{c}\text { Categories } \\
\text { (variables) }\end{array}$ & Subcategories & $\begin{array}{c}\text { Absolute } \\
\text { frequency (n) }\end{array}$ & $\begin{array}{c}\text { Relative } \\
\text { frequency (\%) }\end{array}$ \\
\hline Year of & 2001 & 6 & 2.5 \\
notification & 2002 & 13 & 5.4 \\
& 2003 & 32 & 13.3 \\
& 2004 & 24 & 10 \\
Clinical & 2005 & 55 & 22.8 \\
forms & Cutaneous & 111 & 46.1 \\
& Diffuse & 225 & 93.4 \\
Method of & Only clinical & 16 & 6.6 \\
diagnosis & Clinical and & 25 & 0 \\
& laboratorial & 216 & 89.63 \\
First line & Antimonial drugs & 229 & 99.13 \\
therapy & Amphotericin & 2 & 0.87 \\
History of & New cases & 236 & 97.93 \\
the disease & Recurrent & 5 & 2.07 \\
\hline Total & & 241 & 100 \\
\hline & & & \\
\hline
\end{tabular}

Table 2 - Prevalence of ATL cases notified in Governador Valadares during the period 2001-2006 distributed according to socio-demographic status

\begin{tabular}{|c|c|c|c|}
\hline & $\begin{array}{c}\text { Cases ATL } \\
2001-2006\end{array}$ & $\begin{array}{l}\text { Mean } \\
\text { population } \\
\text { total }\end{array}$ & $\begin{array}{c}\text { Mean yearly } \\
\text { prevalence in } \\
100,000\end{array}$ \\
\hline \multicolumn{4}{|l|}{ Area of origin } \\
\hline Urban & 183 & 236,098 & 12.91 \\
\hline Rural & 58 & 11,033 & 88.22 \\
\hline Total & 241 & $247,131^{*}$ & 101.13 \\
\hline \multicolumn{4}{|l|}{ Gender } \\
\hline Males & 127 & 121,104 & 17.49 \\
\hline Females & 114 & 131,953 & 14.39 \\
\hline Total & 241 & $253,057^{* *}$ & 31.88 \\
\hline \multicolumn{4}{|l|}{ Schooling } \\
\hline$<1$ year & 25 & 16,810 & 24.78 \\
\hline $1-3$ years & 45 & 31,721 & 23.64 \\
\hline $4-7$ years & 71 & 77,523 & 15.26 \\
\hline $8-11$ years & 54 & 33,644 & 26.75 \\
\hline$>12$ years & 12 & 41,019 & 4.87 \\
\hline Total & 207 & 200,717 & 95.30 \\
\hline
\end{tabular}

The frequencies of ATL cases distributed according to age group are shown in figure 1. The largest number of infections occurred in individuals aged $30-39$ years $(n=$ $52 ; 21.58 \%$ ), and, indeed, the majority (some $55 \%$ ) of individuals affected by ATL $(n=132)$ were teenagers and younger adults in the age range 10-39 years old. In contrast, the numbers of ATL cases amongst infants $(\leq 4$ years old) and the elderly ( $\geq 80$ years old) were very small. The two youngest affected individuals were $<1$ year old, and the oldest was 86 years old. However, the prevalence of ATL in the 0 -4-year-old group and the $>80$-year-old group were very different (3.58 and 32.05 per 100,000 inhabitants, respectively) because of the small number of elderly individuals in the study population.

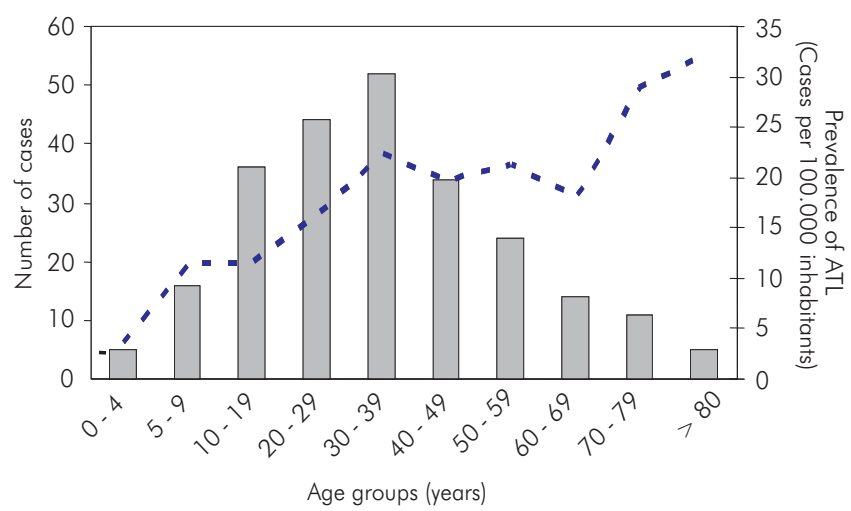

Bars represent the number of cases and the dotted line shows the prevalence profile.

Figure 1 - Distribution of ATL according to age groups and annual average prevalence during the period 2001 2006

Diagnosis of the disease was based on clinical evidence complemented by laboratory tests. The Montenegro skin test was performed in the cases of 191 individuals $(79.25 \%$ of the affected population), 177 of which were positive 
(92.67\%). Histopathological examination of skin samples using hematoxylin eosin was performed on 76 individuals (31.53\% of the affected population), 30 (39.47\%) of which were positive for the presence of the parasite, 41 (53.95\%) of which presented a reaction compatible with ATL and five (6.58\%) of which presented a non-compatible reaction. Direct parasitological tests were performed on only ten individuals (4.15\%), of which six individuals (60\%) were positive for the presence of the parasite and of which four (40\%) were negative. Twenty-five individuals (10.37\%) were diagnosed with ATL exclusively on the basis of clinical evidence because 17 (7.05\%) patients were not submitted to laboratory tests, and eight (3.32\%) patients, despite being submitted to the tests, were either negative for the presence of the parasite or presented a non-compatible reaction.
The cutaneous form of ATL was by far the most common (>90\%). First-line therapy was based mainly on pentavalent antimonial drugs (approximately 99\%), and most ATL cases were newly diagnosed.

Figure 2 shows the census sectors $(n=253)$ of the urban area of Governador Valadares shaded according to the number of cases, thus permitting the identification of areas where ATL was concentrated. Cluster analysis of the results permitted the classification of these census sectors into three groups, as shown in figure 3. The highest prevalence of ATL was in group III (15.99 per 100,000 inhabitants), followed by group II (15.10 per 100,000 inhabitants), whereas group I presented the lowest prevalence (11.38 per 100,000 inhabitants). The absolute and relative frequencies of ATL in these locations are provided in table 3.

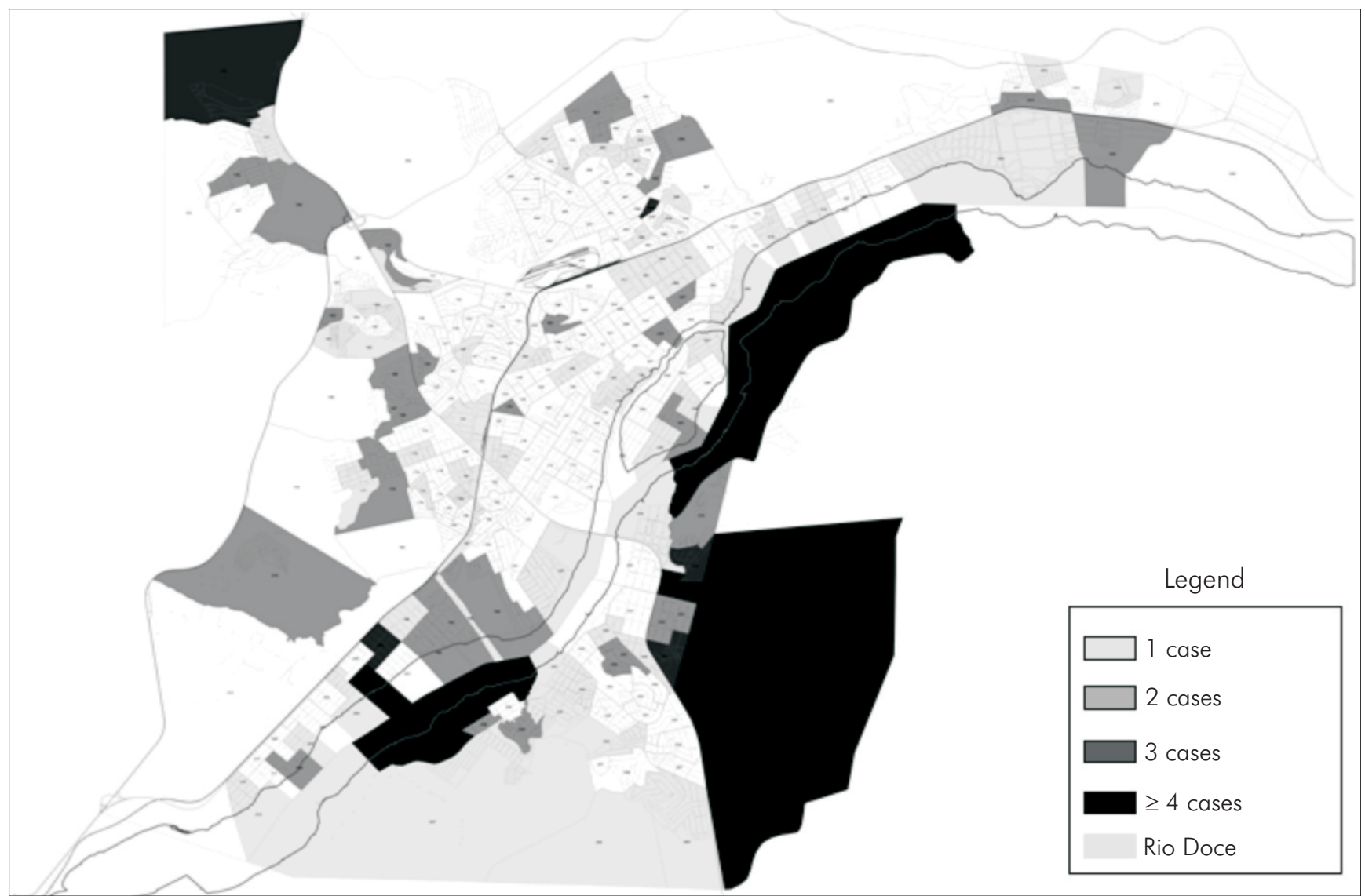

Sectors have been shaded according to the frequency of ATL cases as follows: ( $\square$ ) One case/sector, ( $\square$ ) two cases/sector,

three cases/sector, and

( ) $\geq$ four cases/sector. The area shaded ( ) represents the Rio Doce.

Figure 2 - Urban map of Governador Valadares depicting the number of reported cases of ATL in the various census sectors

Table 3 - Frequencies of ATL cases notified in the urban area of Governador Valadares during the period 2001-2006 distributed according to the three main sector groups

\begin{tabular}{cccccc}
\hline $\begin{array}{c}\text { Sector } \\
\text { groups }\end{array}$ & \multicolumn{2}{c}{ Number of sectors } & Number of ATL cases notified & Prevalence \\
\hline I & $\mathrm{n}$ & $\%$ & $\mathrm{n}$ & \multicolumn{1}{c}{$\%$} & $(100,000)$ \\
\hline II & 155 & 61.26 & 100 & 54.64 & 11.38 \\
III & 26 & 10.28 & 7 & 3.83 & 15.10 \\
\hline Total & 72 & 28.46 & 76 & 41.53 & 15.99 \\
\hline
\end{tabular}




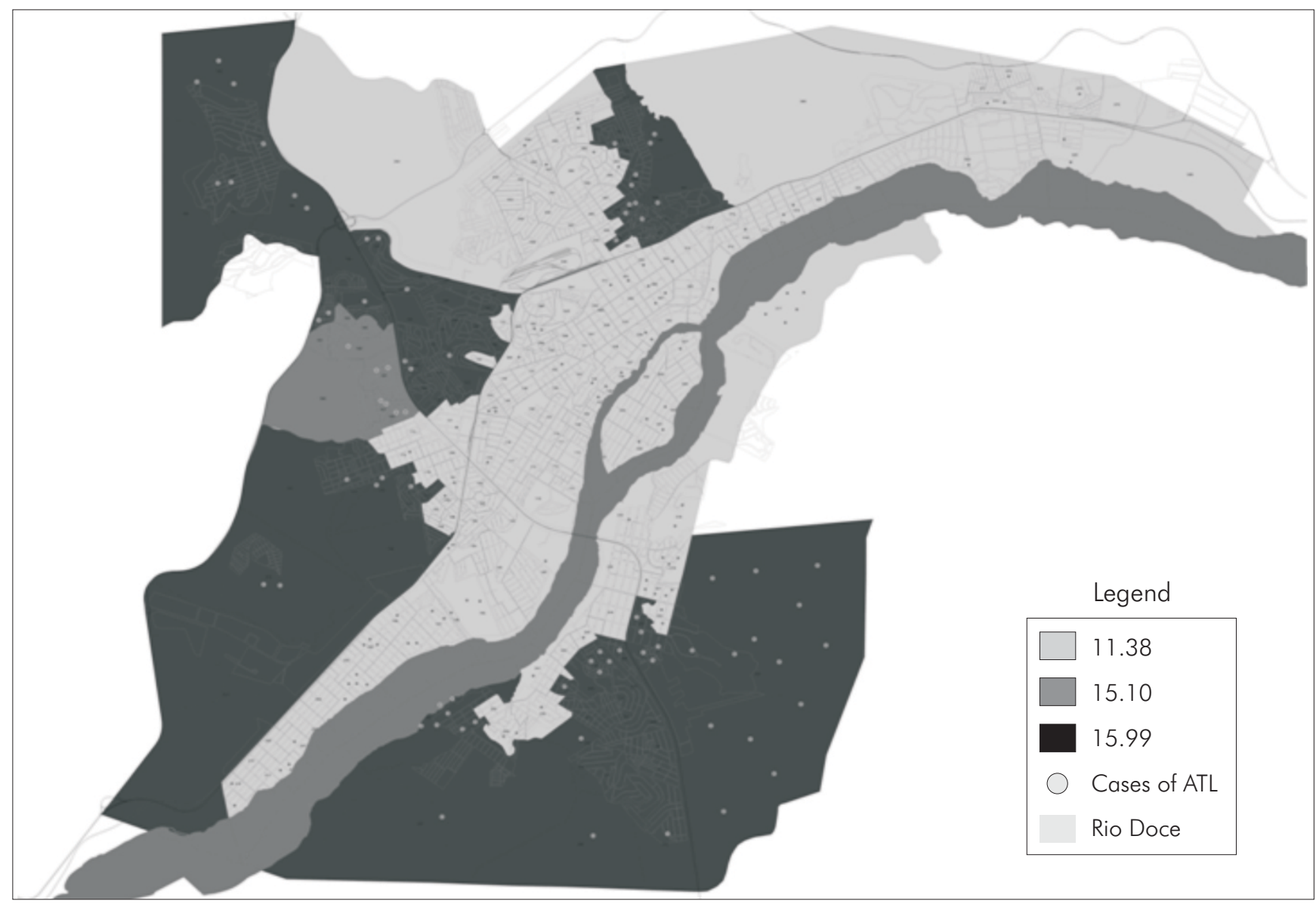

According to cluster analysis, the prevalences of ATL in each sector were $15.99(\square), 15.10(\square)$, and $11.38(\square)$ cases per 100,000 individuals. Dots on the map indicate individuals affected by ATL as reported during the period 2001-2006. The area shaded ( ) represents the Rio Doce.

Figure 3 - Urban map of Governador Valadares divided according to the three main groups of census sectors

\section{DISCUSSION}

The escalating prevalence of ATL in Brazil is causing special concern to the public health authorities due to the high morbidity amongst populations living in endemic areas and because of the urbanization of the disease in recent years, with outbreaks occurring in various state capitals ${ }^{24}$. Moreover, while the reported incidence of ATL has increased substantially, the acknowledged under-reporting of cases still obscures the real magnitude of the problem ${ }^{25}$. According to official sources, the total number of reported cases of ATL in Brazilian territory increased from 3,000 in 1980 to 22,264 in 2006, with peaks of transmission every five years ${ }^{6}$. During the period 2001-2006, the number of reported cases of the disease in Governador Valadares increased by 18.5 fold (from six to 111), whereas the number of cases in Minas Gerais increased slightly (from 1,116 to 1,851), and in Brazil as a whole, the number diminished from 26,636 to 22,264 during the same period.

On the basis of evidence gathered from the period 2001-2006, the prevalence of ATL in the study area appears not to be associated with gender because the numbers of males and females affected by the disease were comparable. This finding corroborates results from previous studies conducted in the Rio Doce valley ${ }^{16}$ and in other endemic areas ${ }^{26,27,28}$. Individuals of all age groups were exposed to the ATL vector independent of work and leisure locations, demonstrating that the disease vector represents a widespread and common problem ${ }^{29}$.
Moreover, the gender and age distribution profiles of the disease suggest a common site of exposure that was probably the domicile and/or its environment.

Although the means of prevalence in rural areas were higher in Governador Valadares, the occurrence of ATL was predominantly urban, a situation most likely resulting from the domestication of the components of the transmission cycle as has been observed in Belo Horizonte and in Manaus, Amazonas State, Brazi ${ }^{20,19,29}$. Alteration of the habits and life style of a population can result in modifications of the environment, particularly changes in temperature and humidity, that may give rise to variations in the transmission patterns of ATL and other diseases. In the case of the Leishmania parasite, domestication is caused primarily by the spread of insect vectors and mammalian hosts to areas inhabited by humans ${ }^{30,8}$.

Diagnoses of the cases of ATL reported during the period 2001-2006 in the study area were based mainly on clinical criteria and on the Montenegro skin test. Histopathological and parasitological tests were performed on only one third of the patients, indicating a lack of laboratory infrastructure within the municipal health units of Governador Valadares. As observed by Luz and coworkers ${ }^{19}$, ill-equipped facilities are a common reality in areas that are endemic for Leishmania, even in state capitals. As for many other diseases, early diagnosis and the application of more refined techniques are important in the control of ATL. 
In the present study, cutaneous ATL predominated over the other forms of leishmaniasis, as has been reported for other endemic areas ${ }^{7,31,28,16,24}$, although $6.6 \%$ of affected individuals presented the mucosal form. The incidence of this more serious form of the disease during the period studied was higher than the national average (3-5\%) and may be associated with various factors such as late diagnosis, parasite virulence, nutritional status and/or comorbidity conditions that altered the immune response of the patients ${ }^{32,33}$.

Although most of the cases recorded related to new patients, approximately $2.1 \%$ were recurrent, a situation that could be a consequence of a series of factors relating to the hosts and parasites or to the medication employed. In Governador Valadares, as in other parts of the world ${ }^{34,24,35}$, first-line ATL therapy consisted of the administration of antimonials, and $95 \%$ of patients received this class of drug. However, the efficacy of therapy depends on many factors including the strain of Leishmania, previous misuse of the medication (with consequential parasite resistance), the number of cutaneous lesions and the expansion of the disease to the mucosas ${ }^{36}$.

Following classification of the census sectors of the urban area of Governador Valadares into three groups according to their common characteristics, it was possible to verify that ATL was less prevalent within the wealthier socio-economic group I (Table 3) who enjoyed the benefit of good sanitation. The prevalences of ATL in groups II and III were similar but much larger than that of group I because of poorer socio-economic status and sanitation conditions that favored the transmission of ATL. However, according to the Secretaria de Vigilância em Saúde, an average ATL detection coefficient in the range $\geq 10$ and $<71$ per 100,000 inhabitants is considered high ${ }^{6}$. Within this context, all three groups in Governador Valadares presented a high detection coefficient and, therefore, require the application of urgent measures (i.e., improved diagnosis facilities and appropriate treatment of the affected individuals) in order to eliminate or minimize the transmission of ATL in the area.

Through analysis of the spatial distribution of leishmaniasis in Rio de Janeiro, Brazil, Kawa and Sabroza ${ }^{28}$ established that the average incidence rates of the disease were greater in zones of intense population growth. The endemic-epidemic dynamics of ATL is associated with human occupation and transformation of the native landscape because adaptation of phlebotomines to houses and their surroundings is favored by the presence of humans and dogs, both of which represent accessible sources of food ${ }^{3}$. Moreover, the presence of vegetation in the vicinity of dwellings favors the appearance of rodents and wild fauna, which are not only potential food sources for phlebotomines but are also hosts for Leishmania spp ${ }^{30}$.

As shown in figure 2, the largest numbers of ATL cases were concentrated in areas located along the margins of the Rio Doce, which traverses Governador Valadares, suggesting its participation in the transmission cycle of Leishmania. These areas clearly demand the urgent and special attention of health authorities and the mobilization of community leaders to confront the problem. A number of studies have demonstrated a positive correlation between the occurrence of ATL and individuals living or working close to rivers ${ }^{37,38}$. Thus, aquifers (rivers and lakes) constitute risk factors for the transmission of ATL because the migration of infected animals to inhabited areas is facilitated. On the other hand, the presence of cats in areas inhabited by humans is considered a protective factor against ATL because these domesticated animals are natural predators of rodents, which are potential Leishmania reservoirs ${ }^{5}$.

The most important aspect with respect to the disturbing situation concerning the spread of ATL in Governador Valadares is due to the educational level of most individuals to be basic. However, knowledge of ATL epidemiology alone might not be sufficient to motive the population to adopt preventive practices, as has been observed by Moreira and co-workers ${ }^{39}$ in Maranhão State, Brazil. As has been previously suggested, the implementation of a concerted effort by health authorities, together with both young and adult members of the community, is essential ${ }^{40,41}$.

\section{CONCLUSION}

In summary, a retrospective descriptive study of ATL in Governador Valadares has been performed for the first time, in which cases reported during the period 2001-2006 were analyzed and spatially distributed according to the urban areas. The difficulty in obtaining data concerning the incidence of the disease in the years preceding the study period demonstrates that there was no previous epidemiological surveillance in the municipality. Furthermore, the results have shown that it is necessary to improve the means of diagnosis and to maintain strict control over the transmission of ATL. Finally, the present study overlaid demographic and socio-economic information relating to small census sectors, as employed by IBGE, onto maps of the municipality supplied by the local public authority Prefeitura Municipal, enabling the risk areas to be readily identified. This type of diagrammatic assessment could be useful in planning the strategies (educational and social programs as well as health policies and investments) needed for the eradication of the debilitating and disfiguring disease of ATL.

\section{ACKNOWLEDGMENTS}

The authors wish to thank the Prefeitura Municipal de Governador Valadares, Minas Gerais State, Brazil, for the provision of data and for most kind assistance with the development of this project.

\section{FINANCIAL SUPPORT}

This work was supported by Fundação de Amparo à Pesquisa do Estado de Minas Gerais (FAPEMIG: grant PRONEX 2007). ABR and RCO are grateful for the fellowships awarded by Conselho Nacional de Desenvolvimento Científico e Tecnológico (CNPq).

\section{ETHICAL APPROVAL}

Details of the project were submitted to and approved by the Ethical Committee in Research of the Universidade do Vale do Rio Doce ( $n^{\circ}$ CEP/UNIVALE 08/2007). 


\section{Estudo descritivo sobre a leishmaniase tegumentar americana na área urbana do Município de Governador Valadares, Estado de Minas Gerais, Brasil RESUMO}

Para entender os padrões de emergência e re-emergência da leishmaniose tegumentar americana (LTA), foram avaliados os perfis clínico e epidemiológico e a distribuição espacial da doença entre 2001 e 2006 em uma área endêmica situada no vale do Rio Doce, no nordeste do Estado de Minas Gerais, Brasil. O número de casos notificados aumentou de seis, no primeiro ano, para 111 no último ano do período estudado. Os casos da doença predominaram na área urbana (75,9\%) e atingiram igualmente homens e mulheres em todas as faixas etárias. A transmissão de LTA ocorreu dentro de residências e em áreas vizinhas, com o maior número de casos registrados oriundo de áreas pobres, sobretudo as localizadas às margens do Rio Doce, sem uma infraestrutura sanitária adequada. O diagnóstico baseou-se em critérios clínicos e no teste de Montenegro. A maioria dos pacientes apresentou a forma cutânea da LTA. $\bigcirc$ tratamento de primeira linha abrangeu a utilização de drogas antimoniais pentavalentes $(99,1 \%)$, que foram responsáveis pela cura de $>75 \%$ dos pacientes. A incidência da LTA variou entre 11,38 e 15,99 casos por 100.000 habitantes, valor alto em comparação com a média nacional. Medidas urgentes, incluindo a melhoria de técnicas de diagnóstico nas unidades de saúde locais, a conscientização de crianças em idade escolar e a motivação da população em geral, são necessárias para reduzir a transmissão da doença e controlá-la.

Palavras-chave: Leishmaniose; Estudos Transversais; Notificação de Doenças; Saúde da População Urbana; Leishmaniose Tegumentar Americana.

\section{Estudio descriptivo sobre la leishmaniasis tegumentaria americana en el área urbana del Municipio de Governador Valadares, Estado de Minas Gerais, Brasil RESUMEN}

Para entender los estándares de emergencia y reemergencia de la leishmaniasis tegumentaria americana (LTA), se evaluaron los perfiles clínico y epidemiológico y la distribución espacial de la enfermedad entre 2001 y 2006 , en una área endémica situada en el valle del Rio Doce, al noreste del Estado de Minas Gerais, Brasil. El número de casos notificados aumentó de seis, el primer año, para 111 el último año del período estudiado. Los casos de la enfermedad predominaron en el área urbana $(75,9 \%)$ y atacaron igualmente a hombres y mujeres en todas las franjas etarias. La transmisión de LTA ocurrió dentro de las casas y en áreas vecinas, con el mayor número de casos registrados originarios de áreas pobres, sobre todo de las localizadas a los márgenes del Rio Doce, sin una infraestructura sanitaria adecuada. El diagnóstico se basó en criterios clínicos y en la prueba de Montenegro. La mayoría de los pacientes presentó la forma cutánea de la LTA. El tratamiento de primera línea involucró la utilización de drogas antimoniales pentavalentes $(99,1 \%)$, que fueron responsables por la cura de $>75 \%$ de los pacientes. La incidencia de la LTA varió entre 1 1,38 y 15,99 casos por 100.000 habitantes, valor alto en comparación con el promedio nacional. Medidas urgentes, incluyendo la mejoría de técnicas de diagnóstico en las unidades de salud locales, la concienciación de niños en edad escolar y la motivación de la población en general, se hacen necesarias para reducir la transmisión de la enfermedad y controlarla.

Palabras clave: Leishmaniasis; Estudios Transversales; Notificación de Enfermedades; Salud Urbana; Leishmaniasis tegumentari americana.

\section{REFERENCES}

1 Lainson R, Shaw JJ. Evolution, classification and geographical distribution. In: Peters W, KillinckKendrick R, editors. The leishmaniases in biology and medicine: biology and epidemiology. London: Academic Press; 1987. p. 1-120.

2 Cupolillo E, Grimaldi Jr G, Momen H. A general classification of new world Leishmania using numerican zymotaxonomy. Am J Trop Med Hyg. 1994 Mar;50(3):296-311.

3 World Health Organization. First WHO report on neglected tropical diseases: working to overcome the global impact of neglected tropical diseases. Geneva: $\mathrm{WHO} ; 2010$.
4 Desjeux P. Leishmaniasis: current situation and new perspectives. Comp Immunol Microbiol Infect Dis. 2004 Sep;27(5):305-18.

5 Salomón OD, Sosa-Estani S, Ramos K, Orellano PW, Sanguesa G, Fernández $G$, et al. Tegumentary leishmaniasis outbreak in Bella Vista City, Corrientes, Argentina during 2003. Mem Inst Oswaldo Cruz. 2006 Nov; 101 (7):767-74.

6 Ministério da Saúde (BR). Secretaria de Vigilância em Saúde. Manual de Vigilância da Leishmaniose Tegumentar Americana. 2. ed. Brasília: Ministério da Saúde; 2007.180 p. 
7 Ampuero J, Macêdo V, Marsden P. Clinical findings of tegumentary leishmaniasis in children under five years of age in an endemic area of Leishmania (Viannia) braziliensis. Rev Soc Bras Med Trop. 2006 JanFeb;39(1):22-6.

8 Costa SM, Cechinel M, Bandeira V, Zannuncio JC, Lainson R, Rangel EF. Lutzomyia (Nyssomyia) whitmani s.l. (Antunes \& Coutinho, 1939) (Diptera: Psychodidae: Phlebotominae): geographical distribution and the epidemiology of American cutaneous leishmaniasis in Brazil - Mini-review. Mem Inst Oswaldo Cruz. 2007 May; 102(2): 149-53.

9 Neuber H. Leishmaniasis. J Dtsch Dermatol Ges. 2008 Sep;6(9):754-65.

10 Marzochi MCA, Marzochi KB. Tegumentary and visceral leishmaniases in Brazil: emerging anthropozoonosis and possibilities for their control. Cad Saude Publica. 1994 Jan; 10 Suppl 2:S359-75.

11 Gontijo B, Carvalho MLR. American cutaneous leishmaniasis. Rev Soc Bras Med Trop. 2003 JanFeb;36(1):71-80.

12 Croft SL, Seifert K, Yardley V. Current scenario of drug development for leishmaniasis. Indian J Med Res. 2006 Mar; 123:399-410.

13 Machado-Pinto J, Pinto J, Costa CA, Genaro O, Marques MJ, Modabber F, et al. Immunochemotherapy for cutaneous leishmaniasis: a controlled trial using killed Leishmania (Leishmania) amazonensis vaccine plus antimonial. Int Soc Dermatol. 2002 Feb;41(2): 73-8.

14 Ovellette M, Drummelsmith J, Papadopoulou B. Leishmaniasis: drugs in the clinic, resistance and new developments. Drug Resist Updat. 2004 AugOct;7(4):257-66.

15 Machado-Coelho GLL, Assunção R, Mayrink W, Caiaffa WT. American cutaneous leishmaniasis in southeast Brazil: space-time clustering. Int J Epidemiol. 1999 Oct;28(5):982-9.

16 Mayrink W, Williams P, Coelho MV, Dias M, Martins AV, Magalhães PA, et al. Epidemiology of dermal leishmaniasis in the Rio Doce valley, State of Minas Gerais, Brazil. Ann Trop Med Parasitol. 1979 Apr;73(2):123-37.

17 Ferreira P. Epidemiologia das leishmanioses. In: Sabroza P, organizador. Glossário de doenças [Internet]. Rio de Janeiro: FIOCRUZ; 2008 [citado 2008 nov 1]. Disponível em: http://www.fiocruz.br/ ccs/cgi/cgilua. exe/sys/start.htm? infoid $=355 \&$ sid $=6$.

18 Zare S, Baghestani S. Cutaneous leishmaniasis in Hormozgan, Iran. Int J Dermatol. 2001 Oct;40(10): 629-31.

19 Luz ZMP, Pimenta DN, Cabral ALLV, Fiúza VOP, Rabello A. Leishmaniasis: urbanization and low diagnosis capacity in the metropolitan region of Belo Horizonte. Rev Soc Bras Med Trop. 2001 May-Jun;34(3):249-54.
20 Guerra JAO, Ribeiro JAS, Coelho LIARC, Barbosa MGV, Paes MG. Epidemiology of tegumentary leishmaniasis in São João, Manaus, Brazil. Cad Saude Publica. 2006 Nov;22(1 1):2319-27.

21 Aleixo J. Leishmaniose com localização genital. An Bras Dermatol Sifilogr. 1945;20:89-91.

22 Furtado TA, Viegas AC. Ensaios terapêuticos na leishmaniose tegumentar americana. An Bras Dermatol. 1967;42(1):47-55.

23 Ministério da Saúde (BR). Departamento de Informática do SUS [Internet]. Brasília [citado 2008 mar 11 ]. Disponível em: http://www.datasus.gov.br.

24 Oliveira-Neto MP, Mattos MS, Perez MA, Da-Cruz AM, Fernandes $O$, Moreira J, et al. American tegumentary leishmaniasis (ATL) in Rio de Janeiro State, Brazil: main clinical and epidemiologic characteristics. Int J Dermatol. 2000 Jul;39(7):506-14.

25 Nunes AG, Paula EV, Teodoro R, Prata A, Silva-Vergara $M L$. Epidemiological aspects of American tegumentary leishmaniasis in Varzelândia, Minas Gerais, Brazil. Cad Saude Publica. 2006;22(6):1343-7.

26 Cunha JCL, Lima JWO, Pompeu MML. Domestic transmission of cutaneous leishmaniasis, during an epidemic in Serra de Baturité, State of Ceará, Brazil. Rev Bras Epidemiol. 2006 Dec;9(4):425-35.

27 Gontijo CMF, Silva ES, Fuccio MB, Sousa MCA, Pacheco RS, Dias ES, et al. Epidemiological studies of an outbreak of cutaneous leishmaniasis in the Rio Jequitinhonha valley, Minas Gerais, Brazil. Acta Trop. 2002 Feb;81 (2): 143-50.

28 Kawa H, Sabroza PC. Spatial distribution of tegumentary leishmaniasis in the city of Rio de Janeiro. Cad Saude Publica. 2002 May-Jun; 1 8(3):853-65.

29 Passos VM, Barreto SM, Romanha AJ, Krettli AU, Volpini AC, Gontijo CM, et al. Cutaneous leishmaniasis in the metropolitan region of Belo Horizonte: clinical, laboratorial, therapeutic and prognosis features (1989-1995). Rev Soc Bras Med Trop. 2001 Jan-Feb;34(1):5-12.

30 Chaves LF, Cohen LM, Pascual M, Wilson ML. Social exclusion modifies climate and deforestation impacts on a vector-borne disease. PLoS Negl Trop Dis. 2008 Feb;2(2):e 176.

31 Castro EA, Soccol VT, Membrive N, Luz E. Epidemiological and clinical study of 332 cases of cutaneous leishmaniasis in the north of Paraná State from 1993 to 1998. Rev Soc Bras Med Trop. 2002 Sep-Oct;35(5):445-52.

32 Machado-Coelho GLL, Caiaffa WT, Genaro O, Magalhães PA, Mayrink W. Risk factors for mucosal manifestation of American cutaneous leishmaniasis. Trans R Soc Trop Med Hyg. 2005 Jan;99(1):55-61. 
33 Passos VMA, Falcão AL, Marzochi MCA, Gontijo CMF, Dias ES, Barbosa-Santos EGO, et al. Epidemiological aspects of American cutaneous leishmaniasis in a periurban area of the metropolitan region of Belo Horizonte, Minas Gerais, Brazil. Mem Inst Oswaldo Cruz. 1993 Jan-Mar;88(1): 103-10.

34 Brochu C, Wang J, Roy G, Messier N, Wang XY, Saravia $N G$, et al. Antimony uptake systems in the protozoan parasite Leishmania and accumulation differences in antimony-resistant parasites. Antimicrob Agents Chemother. 2003 Oct;47(10):3073-9.

35 Rastogi V, Nirwan PS. Cutaneous leishmaniasis: an emerging infection in a non-endemic area and a brief update. Indian J Med Microbiol. 2007 Jul;25(3): 272-5.

36 Rodrigues AM, Hueb M, Santos TARR, Fontes CJF. [Factors associated with treatment failure of cutaneous leishmaniasis with meglumine antimoniate]. Rev Soc Bras Med Trop. 2006 Mar-Apr;39(2): 139-45.

37 Ryan JR, Mbui J, Rashid JR, Wasunna MK, Kirigi G, Magiri $C$, et al. Spatial clustering and epidemiological aspects of visceral leishmaniasis in two endemic villages, Baringo district, Kenya. Am J Trop Hyg. 2006 Feb;74(2):308-17.
38 Salomón OD, Orellano PW, Lamfri M, Scavuzzo M, Dri $\mathrm{L}$, Farace MI, et al. Phlebotominae spatial distribution associated with a focus of tegumentary leishmaniasis in Las Lomitas, Formosa, Argentina, 2002. Mem Inst Oswaldo Cruz. 2006 May; 101 (3):295-9.

39 Moreira RCR, Rebêlo JMM, Gama MEA, Costa JML. Nível de conhecimento sobre leishmaniose tegumentar americana (LTA) e uso de terapias alternativas por populações de uma área endêmica da Amazônia do Maranhão, Brasil. Cad Saude Publica. 2002 jan-fev; 18(1): 187-95.

40 Costa JML, Vale KC, França F, Coatá MAF, Silva JO, Lago $\mathrm{EL}$, et al. A leishmaniose tegumentar americana em uma região endêmica como fator de mobilização comunitária. Rev Soc Bras Med Trop. 1994 outdez;27(4):255-7.

41 Freitas JS, Santana RG, Melo SR. A survey on cases of leishmaniosis recorded at the municipal district of Jussara, Paraná, Brazil. Arq Ciencias Saude UNIPAR. 2006 Jan-Apr; 10(1):23-7.

Received / Recebido em / Recibido en: 21/7/2010 Accepted / Aceito em / Aceito en: 16/2/201 1 